\title{
Foraminiferal assemblages as palaeoenvironmental bioindicators in Late Jurassic epicontinental platforms: Relation with trophic conditions.
}

\author{
Matias Reolid, Jenö Nagy, Francisco J. Rodríguez-Tovar, and Federico Olóriz \\ Acta Palaeontologica Polonica 53 (4), 2008: 705-722 doi:http://dx.doi.org/10.4202/app.2008.0413
}

Foraminiferal assemblages from the neritic environment reveal the palaeoecological impact of nutrient types in relation to shore distance and sedimentary setting. Comparatively proximal siliciclastic settings from the Boreal Domain (Brora section, Eastern Scotland) were dominated by inner-shelf primary production in the water column or in sea bottom, while in relatively seawards mixed carbonate-siliciclastic settings from the Western Tethys (Prebetic, Southern Spain), nutrients mainly derived from the inner-shelf source. In both settings, benthic foraminiferal assemblages increased in diversity and proportion of epifauna from eutrophic to oligotrophic conditions. The proximal setting example (Brora Brick Clay $\mathrm{Mb}$.) corresponds to Callovian offshore shelf deposits with a high primary productivity, bottom accumulation of organic matter, and a reduced sedimentation rate for siliciclastics. Eutrophic conditions favoured some infaunal foraminifera. Lately, inner shelf to shoreface transition areas (Fascally Siltstone Mb.), show higher sedimentation rates and turbidity, reducing euphotic-zone range depths and primary production, and then deposits with a lower organic matter content (high-mesotrophic conditions). This determined less agglutinated infaunal foraminifera content and increasing calcitic and aragonitic epifauna, and calcitic opportunists (i.e., Lenticulina). The comparatively distal setting of the Oxfordian example (Prebetic) corresponds to: (i) outer-shelf areas with lower nutrient input (relative oligotrophy) and organic matter accumulation on comparatively firmer substrates (lumpy lithofacies group) showing dominance of calcitic epifaunal foraminifera, and (ii) mid-shelf areas with a higher sedimentation rate and nutrient influx (low-mesotrophic conditions) favouring potentially deep infaunal foraminifers in comparatively unconsolidated and nutrient-rich substrates controlled by instable redox boundary (marl-limestone rhythmite lithofacies).

Key words: Foraminifera, neritic shelf, trophic conditions, Jurassic, Boreal Realm, Tethys.

Matías Reolid [mreolid@ujaen.es], Departamento de Geología, Universidad de Jaén, Campus Las Lagunillas, 23071 Jaén, Spain; Jenö Nagy [jeno.nagy@geo.uio.no], Institutt for geofag, Universitetet i Oslo, Postbox 1047, Blindern, N-0316 Oslo, Norway; Federico Olóriz [foloriz@ugr.es], Departamento de Estratigrafía y Paleontología, Universidad de Granada, Fuentenueva s/n, 18002 Granada, Spain. 
This is an open-access article distributed under the terms of the Creative Commons Attribution License (for details please see creativecommons.org), which permits unrestricted use, distribution, and reproduction in any medium, provided the original author and source are credited.

FaF Full text $(804.9 \mathrm{kB})$ ।

FDF 